\title{
Pollination and Predation Limit Fruit Set in a Shrub, Bourreria succulenta (Boraginaceae), after Hurricanes on San Salvador Island, Bahamas ${ }^{1}$
}

\author{
Beverly J. Rathcke ${ }^{2}$ \\ Department of Biology, University of Michigan, Ann Arbor, Michigan 48109-1048, U.S.A.
}

\begin{abstract}
Hurricanes have been assumed to reduce the reproduction of plants, either directly by leaf stripping and stress or indirectly by reducing pollinators. I examined the pollination and fruit set of a common shrub, Bourreria succulenta, after hurricanes on San Salvador island, Bahamas. Contrary to the assumption of resource limitation, B. succulenta showed unusually prolific flowering after Hurricane Lili stripped leaves from most of the plants in October 1996.1 predicted that the abundant flowering would saturate pollinators and that fruit set would be pollination-limited. Fruit set was strongly pollination-limited by 71 percent. Butterflies are probably the major pollinators and were present at the site, but they rarely visited $B$. succulenta flowers even though flowers were brimming with nectar. Nectarivorous birds (Bananaquits and Bahama Woodstars) visit B. succulenta flowers, but their populations were decimated by Hurricane Lili and they rarely visited flowers during this time. Fruit set was also severely predation-limited; a moth caterpillar (Gelechiidae) was extremely abundant and ate buds, flowers, and fruits, causing a further 68 percent reduction in fruit set. Together, pollination limitation and predation limitation reduced fruir set to only 7 percent or less. Predation was also intense in 1999 after Hurricane Floyd and resulted in 11 percent fruit set or less. Whether or not hurricanes were the cause of limited pollinators or abundant predators, the resulting low fruit set could have population effects because hurricanes can provide opportunities for the recruitment of new plants. These results emphasize that understanding plant-animal interactions may be necessary for predicting the effects of hurricanes on plant reproductive success, which may affect subsequent recruitment. Species on small islands like San Salvador (150 $\mathrm{km}^{2}$ ) with relatively few species may be especially vulnerable to environmental disturbances such as hurricanes.
\end{abstract}

Key words: Babamas; Bourreria; flower predation; fruit predation; fruit set; burricane effects; island pollination; plantanimal interactions; pollination limitation; scrublands.

UNDERSTANDING THE EFFECTS OF HURRICANES ON PLANTS is a topic that has received much recent attention. Studies have documented that hurricanes can strip plants of their leaves and provide other stresses, such as high rainfall, high winds, or salt spray, which destroy flower and fruit resources for some time afterwards (Reilly 1991, Walker et al. 1992, Boose et al. 1994, Zimmerman et al. 1994, Bronstein \& Hossert-McKey 1995, Grant et al. 1997, Pascarella 1998a). These stresses might also be expected to decrease the ability of plants to produce flowers or fruit after the hurricane; however, subsequent flower production after hurricanes was not significantly reduced in an orchid (Ackerman \& Moya 1996), a fig species (Bronstein \& HossertMcKey 1995), or Pavonia bahamensis on San Salvador, Bahamas (Rathcke 2000a,b), and even increased in a shrub (Pascarella 1998b). In addition, fruit set did not appear to be resource-limited in two of these species, the orchid and fig (Bronstein \& Hossert-McKey 1995, Ackerman \& Moya

\footnotetext{
Received 15 August 1999; revision accepted 22 March 2000.

2 E-mail: brathcke@umich.edu
}

1996), although resource limitation significantly reduced fruit set for $P$. bahamensis (Rathcke 1998, 2000a).

Fruit set also can be limited indirectly by hurricanes if pollinator populations are reduced. Many studies have shown that hurricanes commonly devastate populations of nectarivorous birds, and researchers have assumed that this occurs because these birds are left with few nectar or fruit resources (Askins \& Ewert 1991, Lynch 1991, Waide 1991, Will 1991, Wauer \& Wunderle 1992, Wunderle et al. 1992, Wunderle 1995, Murphy et al. 1998). One study has demonstrated that this decline in nectarivorous birds can cause pollination limitation of fruit set (Rathcke 1998, 2000a); however, other pollinators, such as insects, have been found to rebound quickly or perhaps even increase because of hurricane effects. A hawkmoth pollinator of an orchid appeared to become a more common visitor after a hurricane although pollen deposition was lower (Ackerman \& Moya 1996). Fig wasps appeared to return to pre-hurricane levels within months after Hurricane Hugo (category 4) in Florida (Bronstein \& Hossert-McKey 1995). No 
change in the pollinator community was found in pre- and post-hurricane surveys of a tropical shrub (Pascarella 1998b). Responses by insects to hurricanes are likely to be highly specific and may tend to be positive, whereas responses of nectarivorous birds may be generally negative. Whether insectpollinated plants typically have a lower risk of pollination limitation than bird-pollinated plants after hurricanes remains to be documented.

Because island species often have fewer pollinators than mainland species (Carlquist 1974; Woodell 1979; Feinsinger et al. 1982, 1985; Spears 1987; Elmqvist et al. 1992; Inoue 1993; Barrett 1996), plants on small islands may be especially vulnerable to disturbances such as hurricanes that disrupt their pollinators or other mutualists (Rathcke 1998, 2000a). In general, environmental changes such as global warming, habitat destruction, or introduced species may have especially strong effects on islands (Loope \& Mueller-Dombois 1989; cf. Simberloff 1995) because species are so few and little buffering and compensation is possible. Small islands such as San Salvador, which is only $150 \mathrm{~km}^{2}$, may be especially vulnerable to environmental disturbances and species changes (Eshbaugh \& Wilson 1996).

In this study, I documented the pollination and fruit set of a common shrub, Bourreria succulenta (Boraginaceae), or strongback, on San Salvador island, Bahamas, after three hurricanes in 1996. Following these hurricanes in December/January of $1996 / 1997$, flowers of $B$. succulenta were unusually abundant and evident throughout the island (Rathcke $e t$ al. in press). In two earlier winter visits in $1994 / 1995$ and 1995/1996, the species was flowering, but flowers were not especially abundant or remarkable. As a consequence, I decided to study its pollination and fruit set during this period of unusually heavy flowering. I hypothesized that fruit set may be pollination-limited because flowers were so abundant that they seemed likely to saturate the pollinators. I tested this hypothesis by measuring initial fruit set of naturally pollinated and pollenaugmented flowers. During the study, it became evident that flower/fruit predation was significant, so I quantified predation limitation of fruit set and compared the relative effects of both pollination and predation limitation of fruit. I also report on further observations on pollination and predation in June 1999 and in November/December 1999.

\section{STUDY SPECIES}

Bourreria succulenta Jacq. (= B. ovata Miers; Boraginaceae), strongback or strongbark, is a shrub or small tree that grows throughout the Bahamas, Florida, and Cuba in scrublands coppice (Correll \& Correll 1982, Al-Shehbaz 1991, Wunderlin 1998). The breeding system, floral biology, and pollination of this species have been described only recently (Rathcke et al. in press). Plants are selfincompatible, and flowers require an animal pollinator for fruit set. Flowers last two days; corollas are white on the first day and beige on the second day after anthesis. Flowers have a salverform corolla ca $1.5 \mathrm{~cm}$ in diameter with a short floral tube $(\mathrm{ca}$ $1 \mathrm{~cm}$ long) and are displayed in cymes (Correll \& Correll 1982; Rathcke, pers. obs.). Abundant flowering occurred between mid-December and early January in 1996/1997, and during November/early December in 1999, although the species can flower sporadically throughout the year (Correll \& Correll 1982, Scurlock 1987, Wunderlin 1998). A shrub typically displays 5-15 white flowers simultaneously during peak flowering. Fruits are red drupes. The leaves are used medicinally in teas for increasing strength (White 1985) and alleviating back and waist pain (Jordan 1986); the fruits are eaten by people and birds (Scurlock 1987).

\section{STUDY SITE}

San Salvador is one of the easternmost islands in the Bahama archipelago $\left(24^{\circ} 05^{\prime} \mathrm{N}, 74^{\circ} 30^{\prime} \mathrm{W}\right)$ (Shaklee 1996). The island is ca $19 \mathrm{~km}$ long and $8 \mathrm{~km}$ wide (Smith 1993) and $150 \mathrm{~km}^{2}$. The coolest months (January and February) average $22^{\circ} \mathrm{C}$, and the warmest months (July and August) average $28^{\circ} \mathrm{C}$ (Shaklee 1996). Total mean annual rainfall is $1007 \mathrm{~mm}$ (Shaklee 1996).

The study site is located near the Bahamian Field Station at the northern end of San Salvador. I studied shrubs growing along the path to Reckley Hill Pond southeast of the Bahamian Field Station. Bourreria scculenta grows throughout the scrubland community (Blacklands Coppice), which is the most common vegetation type on San Salvador (Smith 1993). The scrubland coppice is diverse with no dominant species (Smith 1993) and is so dense that paths must be cut in order to walk through the vegetation.

Hurricanes on San Salvador-In the Bahamas archipelago, hurricanes occur on average every three years; bur in an unusually quiet period, no hurricanes affected San Salvador between 1981 and 1994 (Shaklee 1996). In 1995, one mild hurricane (Erin) passed west of San Salvador with winds up to 75 miles per hour, causing little damage. In 
1996, three hurricanes struck San Salvador. Hurricane Bertha in July and Hurricane Fran in September caused little damage (Bahamas Department of Meteorology n.d.); but on October 19, the eye of Hurricane Lili passed directly over the island with winds up to 105 miles per hour and heavy rainfall $(711 \mathrm{~mm}$ on San Salvador over four days starting 17 October; Bahamas Department of Meteorology n.d.). Lili was a category 2 storm and caused extensive damage to buildings. It stripped many trees of their leaves (Murphy et al. 1998) and was an unusually severe hurricane for the island. On 14 September 1999, Hurricane Floyd, an intense category 4 hurricane, passed directly over San Salvador with winds up to 150 miles per hour and dropped $196 \mathrm{~mm}$ of rain in one day on San Salvador (Bahamian Field Station records).

\section{METHODS}

Twelve $B$. succulenta trees at the study site were permanently tagged and followed from 19 December 1996 to 5 January 1997, which included the major flowering period. Abundant flowering also occurred in November/early December 1999 (N. Elliott, pers. comm.). I recorded fruit set for these and other trees in mid-December 1999. Bourreria succulenta flowers sporadically throughout the year (Correll \& Correll 1982; Scurlock 1987; Wunderlin 1998; Rathcke, pers. obs.). For example, in June 1999, four individuals were seen flowering in extensive general surveys of the coppice at three sites (Reckley Hill Pond, Osprey Pond, and Hard Bargain Trail) in which hundreds of $B$. succulenta trees were surveyed.

Flower visitors were noted and recorded throughout the study in 1996/1997 and in June 1999. N. Elliott noted visitors in November 1999. In 1996/1997, spot surveys lasting about one minure per tree were made periodically throughout the day for all trees along the path. In addition, timed ten-minute watches of a known number of flowers were made on several occasions.

Standing crop of nectar was measured as an indicator of pollinator visitation. Standing crop of nectar was measured in exposed, unbagged flowers on the same plants at the same time as nectar production in bagged flowers was measured. Nectar in flowers was measured using 5-microliter capillary tubes. A Bellingham refractometer was used to measure sugar concentrations. Brix values were converted to sucrose equivalents according to Bolten et al. (1979).

To test for pollination limitation of fruit set, two budded inflorescences (cymes) on each of 15 shrubs were tagged and assigned to one of two pollination treatments. (1) In the augmented crosspollen treatment, cross-pollen from an individual at least $4 \mathrm{~m}$ distant was added to stigmas each day the stigma was glistening (usually two days). (2) In the natural pollination treatment, flowers were marked but were unmanipulated and exposed to natural pollination. Flower predators were removed; any inflorescences with predator damage were excluded.

Fruit set was calculated as: percent fruit set $=$ 100 (fruits/flowers). Fruit set was based on the development and expansion of the ovary because the study had to be terminated before any fruits had matured. Ten days after flower opening, it was apparent whether or not the ovary would develop or would fall. Many ovaries were $5-7 \mathrm{~mm}$ in diameter at the termination of this study. Mature fruit was 10-12 mm in diameter (Correll \& Correll 1982). For the final assessment of fruit set, all buds that did not have sufficient time to potentially develop fruit or were ambiguous as to ovary development or loss, were excluded from the calculations of fruit set. These excluded buds consisted of unopened buds, recent flowers, and damaged or eaten buds, flowers, or developing fruit. Fruit set from control inflorescences was also calculated, taking into account both potential pollination limitation and predation. Fruit set from an additional random sample of 10 to 12 inflorescences/tree was also recorded to further quantify the fruit set of flowers exposed to natural pollination and predation.

A relative measure of pollination limitation (PL) of fruit set (Rathcke 2000a) was calculated by comparing the percent fruit sets (\%FS) of pollen augmented $(\mathrm{P}+)$ flowers and naturally pollinated flowers $(\mathrm{NP}): \% \mathrm{PL}=100(\% \mathrm{FS}$ of $\mathrm{P}+)-(\% \mathrm{FS}$ of $\mathrm{NP}) /(\% \mathrm{FS}$ of $\mathrm{P}+$ ). If fruit set of naturally pollinated flowers and augmented flowers are equal, then PL $=0$ percent. If fruit set is zero for naturally pollinated flowers and $>0$ for pollen-augmented flowers, then \%PL equals 100 percent.

Because predation on buds, flowers, and developing fruit was common, I also calculated a relative predation limitation index (PRL) by comparing fruit sets of naturally pollinated flowers that had no predation in treatments (PR-) with naturally pollinated flowers that were exposed to predation: $(\mathrm{PR}+): \% \mathrm{PRL}=100(\% \mathrm{FS}$ of $\mathrm{PR}-)-(\% \mathrm{FS}$ of $\mathrm{PR}+) /(\% \mathrm{FS}$ of $\mathrm{PR}-)$. If predation does not reduce fruit set, then \%FS of PR $+=$ the $\% F S$ of PRand the \%PRL is zero. If predation kills all the 
TABLE 1. Standing crop of nectar and nectar production is not significantly different, indicating low nectar removal from flowers of Bourreria succulenta (based on per-day measurements). Means, standard deviations, and numbers of plants and flowers are shown in parentheses. Means are not significantly different for any index; Student's t-tests, $\mathrm{P}>0.30, \mathrm{~N}=7$ plants.

\begin{tabular}{lccc}
\hline & & \multicolumn{2}{c}{ Sucrose equivalents } \\
\cline { 3 - 4 } & Nectar/flower $(\mu \mathrm{l})$ & $\mathrm{mg} / \mathrm{ml}$ & $\mathrm{mg} /$ Hower \\
\hline Standing crop $(7,21)$ & $8 \pm 5.4$ & $0.29 \pm 0.068$ & $2.5 \pm 1.64$ \\
Nectar production/day $(7,36)$ & $10 \pm 5.7$ & $0.29 \pm 0.070$ & $3.0 \pm 1.76$ \\
\hline
\end{tabular}

fruits $(\% \mathrm{FS}$ of $\mathrm{PR}+=0)$, then $\% \mathrm{PRL}=100$ percent.

Statistics were done using Systat version 5.01. Significant differences were tested with Student's $t$ tests. Data sets with percent fruit set were tested using arcsine-transformed values to normalize distributions. Sample sizes $(N)$ are plants, each plant having many experimental flowers unless otherwise noted.

\section{RESULTS}

Fruit set was strongly pollination-limited (Table 2). Naturally pollinated flowers (with no predation) had 22 percent fruit set $(S D=23.7)$, whereas flowers with cross-pollen added had 77 percent fruit set (SD $=20.6 ; P<0.0001$; Student's $t$-test on arcsine-transformed data; $N=12$ plants). Plants are self-incompatible and require pollinators for outcrossing and fruit set (Rathcke et al. in press).

This pollination limitation was caused by lack of flower visitors. Visitors to flowers were seldom observed in winter 1996/1997. During five days of one to four spot surveys of 30 plants and two tenminute watches, no flower visitors were seen. While making other observations during the ten days of study, the following visitors were seen on flowers: one pierid butterfly (possibly Kricogonia lyside Godart), two wasps, one large black bee (possibly a carpenter bee, Xylocopa [Neoxylocopa] cubaecola Lucas; Elliotr 1993), two warblers (including one Yellow Warbler, Dendroica petechia; Parulidae), and one Bananaquit (Coereba flaveola; Emberizidae, Coerebinae). All of these individual visitors stayed only briefly on a plant, visiting one or a few flowers before leaving, except the Bananaquit, which visited four flowers and then visited a nearby red anneslia (Calliandra haematomma). During this study, many butterflies (especially Pieridae and Lycaenidae) and wasps were seen flying close to the shrubs. These species almost never visited flowers of $B$. succulenta, although they visited flowers of other species. In November 1999, Nancy Elliott observed four butterfly species visiting flowers, although visits were infrequent (Rathcke et al. in press). Migratory warblers (especially Yellow Warblers) occasionally visited flowers of many species, but visits were infrequent and they seemed unlikely to be major pollinators of $B$. succulenta even during the winter season.

The lack of flower visitors during winter 1996/ 1997 is supported by lack of nectar removal from flowers. The standing crop of nectar (microliters) in open flowers measured at the end of the day was not significantly different than nectar production in bagged flowers over the same time period (Table 1). The sugar concentration of nectar (sucrose equivalents) was equivalent between open and bagged flowers; so total milligrams of sugar (measured as sucrose equivalents) was also not significantly different between open and bagged flowers (Table 1).

In 1996/1997, fruit set was strongly predationlimited by a moth caterpillar (Gelichiidae) (Table 2). Fruit set of flowers exposed to predation was 7

TABLE 2. Relative pollination limitation and predation limitation of fruit set in Bourreria succulenta on San Salvador island, Bahamas. Percent fruit set $=\%$ (fruit/flowers). Limitation shows the percent reduction of maximum fruit by pollination, predation, and both. See text for equations and discussion.

\begin{tabular}{lcc}
\hline \multicolumn{1}{c}{ Limitation factor } & Equation (\%) & Limitation (\%) \\
\hline Pollination & PL $=(77-22) / 77$ & 71 \\
Predation & PRL $=(22-7) / 22$ & 68 \\
Pollination and Predation & PPL $=(77-7) / 77$ & 91 \\
\hline
\end{tabular}


percent ( $\mathrm{SD}=6.1, N=12$ plants), whereas fruit set of protected flowers with natural pollination was 22 percent $(\mathrm{SD}=23.7, N=15$ plants; means were significantly different, $P=0.03$, Student's $t$ test on arcsine-transformed data). The caterpillars bored into the buds or entered the flowers and ate the filaments and style and ovaries or bored directly into the developing ovary. Caterpillars moved between flowers and often damaged most of the flowers in a cyme. The gelichid caterpillar was probably an undescribed species (D. Davis \& D. Adamski, pers. comm.).

Because of both pollination and predation limitation in $1996 / 1997$, fruit set was very low (7\%). Pollination limitation is estimated to have reduced fruit set by 71 percent, and predation is estimated to have further reduced fruit set by another 68 percent (Table 2). It is possible that predators would have limited fruit set to the same low level without pollination limitation occurring. Regardless of their interaction, pollination and predation limitation together are estimated to have reduced fruit set from its potential maximum by 91 percent (Table 2 ). In a larger survey of nonexperimental infloresences on shrubs, fruit set with both pollination and predation limitation was estimated to be 7.3 percent $(S D=6.14, N=12 ; 12$ plants, 127 inflorescences, 1154 flowers). The 7 percent fruit set is probably a conservative value because predation continued after the study had to be terminated and may have caused a complete failure of fruit set.

In December 1999 after Hurricane Floyd, the gelechid caterpillar was abundant and again damaged or killed many buds and developing fruits. Fruit set was estimated to be 9 percent based on the average fruit per inflorescence on 10 December 1999 (1.11 $\pm 1.245, N=14 ; 14$ plants, 270 inflorescences) and average inflorescence size in 1998 (12 \pm 4.7 flowers, $N=12$; 12 plants, 44 inflorescences). Further fruit mortality probably occurred after this assessment. Pollination studies were not done in 1999; thus pollination limitation cannot be assessed, although fruit production (before predation) appeared to be low. In June 1999 when flowering was very sparse, this gelichid caterpillar was also found in flowers or fruits on two of the four shrubs that were observed flowering.

\section{DISCUSSION}

Fruit set of $B$. succulenta was strongly limited by both pollination and predation in winter 1996/ 1997 after major hurricanes. The extremely low fruit set $(7 \%)$ of $B$. succulenta was caused by both pollination and predation limitation, although predation alone may have be able to cause the 91 percent reduction in fruit set observed. Predation by a moth caterpillar (Gelechiidae) probably continued after the study was terminated and may well have caused a total failure of fruit set. Predation by this caterpillar also caused low fruit set $(11 \%$ or less) in 1999 after Hurricane Floyd. Why did pollinators and predators limit fruit set so strongly in this common shrub after the hurricanes?

Although I had hypothesized that fruit set would be pollination-limited after the hurricanes because the unusually abundant flowering would saturate the pollinators, this was true only in a trivial sense. More accurately, virtually no pollinators were observed visiting the flowers; and seemingly potential pollinators such as butterflies and wasps ignored the $B$. succulenta flowers while occasionally visiting flowers of other nearby species. Nectar was available but seldom removed although it appeared to be accessible to many insects and birds (because it accumulated at the top of the corolla). The reason for this lack of flower visitation is puzzling.

One explanation for the lack of pollinators is that $B$. succulenta is specialized for a insect pollinator that was rare or absent during this flowering season, perhaps because of the hurricane. Campbell (1978) has described B. succulenta as one of the "butterfly trees" of the scrublands coppice on New Providence island, and has documented how the white fragrant flowers attract hundreds of ringlet butterflies (Calisto herophile). A subspecies, Calisto herophile apollinis Bates (Satyridae), occurs on San Salvador, but is not common (Riley 1975, Elliott et al. 1980, Elliott 1993) and has never been observed visiting $B$. succulenta flowers; however, we observed four other butterfly species visiting $B$. succulenta flowers, although visits were infrequent (Rathcke et al. in press). Miller et al. (1992) recorded ten butterfly species visiting flowers in the southern Bahamas. J. Ackerman (pers. comm.) observed butterflies visiting a Bourreria species (possibly $B$. succulenta) on Mona island. Butterflies are frequent flower visitors to $B$. succulenta in Florida (Scurlock 1987). Other insects occasionally visited $B$. succulenta flowers on San Salvador, including wasps and bees (Xylocopa). J. Pascarella (pers. comm.) caught a carpenter bee, Xylocopa micans, visiting flowers in Florida. These observations suggest that $B$. succulenta is not specialized for one or a few pollinator species; instead, many butterfly species, as well as other insect species, visit flowers and may be pollinators.

Resident nectarivorous birds, Bahama Woodstars 
and Bananaquits, also visit B. succulenta flowers, but these were rare after being decimated by Hurricane Lili in October 1996 (Murphy et al. 1998; Rathcke 1998, 2000a). Severe population reductions after hurricanes also have been observed for nectarivorous birds in other studies (Askins \& Ewert 1991, Lynch 1991, Waide 1991, Will 1991, Wauer \& Wunderle 1992, Wunderle et al. 1992, Wunderle 1995). The scarcity of these two bird species caused severe pollination limitation of fruit set in another shrub species, P. bahamensis (Malvaceae) on San Salvador island (Rathcke 1998, 2000a) and may have contributed to the pollination limitation of fruit set in B. succulenta. Bahama Woodstars were the only species seen visiting flowers in June 1999 when fruit set was high, and thus appear to be effective pollinators (Rathcke et al. in press).

Although several types of insects and birds visited flowers of $B$. succulenta, the pollination syndrome (floral traits adapted to a pollinator type) most closely matches that of a butterfly-pollinated species (Rathcke et al. in press). Flowers are white, fragrant, and small; i.e., the corolla is $1.5 \mathrm{~cm}$ wide and the floral tube is $0.9 \mathrm{~cm}$ long, and the stamens and styles are short, extending only a few millimeters above the corolla. These traits do not match those described for a bird-pollination syndrome in which flowers are expected to be red and odorless with long corolla tubes and exserted anthers and stigmas. In addition, nectar was more concentrated (29\%) and volume was lower (ca 10 microliters/ flower/day) than that reported for most bird-pollinated flowers, although nectar production was higher than reported for most butterfly-pollinated flowers (Rathcke et al. in press). It is possible that both butterflies and birds are major pollinators of B. succulenta on San Salvador. The lack of a match between pollinators and a pollination syndrome is not unusual and recently has caused pollination syndromes to be viewed skeptically and cautiously (Schemske 1983, Herrera 1996, Ollerton 1996, Waser et al. 1996). Often, flowers categorized in one pollination syndrome are pollinated effectively by other types of pollinators, and specialization for a single pollinator type seems to be relatively rare (Baker et al. 1971, Schemske 1983, Schemske \& Horvitz 1984, Feinsinger 1987). Specialization for a few pollinator species can increase the risk of pollination limitation (Rathcke \& Jules 1993; Rathcke $1998,2000 \mathrm{a}, \mathrm{b})$, whereas generalization for many pollinators may reduce this risk (Rathcke 1988, Waser et al. 1996).

Bourreria succulenta appears to be quite gener- alized for pollinators, but fruit set was still pollination-limited. Butterflies, wasps, bees, and birds, which are generalists on many flowering species, all visited $B$. succulenta flowers but were rare visitors. The lack of visits by birds can be explained by the devastation from Hurricane Lili (Murphy et al. 1998; Rathcke 1998, 2000a), but why insects did not provide adequate, compensatory pollination is not clear. In contrast to other studies in which insect pollinators rebounded quickly after hurricanes and were abundant flower visitors (Bronstein \& Hossert-McKey 1995, Ackerman \& Moya 1996), insect pollinators were rare for $B$. succulenta. Whether this insect rarity on San Salvador was caused by the hurricanes is not known. The lack of compensatory pollination could reflect the low species richness and low population sizes on small islands like San Salvador $\left(150 \mathrm{~km}^{2}\right)$. San Salvador has 43 butterfly species (Elliott et al. 1980, pers. comm.); however, we observed only 4 species visiting $B$. succulenta and they were infrequent. Honeybees (Apis mellifera) and bumblebees (Bombus spp.) were absent and other native bees were relatively rare (Elliotr 1993; Rathcke et al. in press); so bees typically may be infrequent visitors. Whatever the cause of the scarcity of pollinators, these results have demonstrated that a common plant species with a generalized pollination system can be pollination-limited on a small island.

Although insect pollinators were rare for $B$. succulenta, an insect predator (a moth caterpillar: Gelechiidae) was extremely abundant and caused severe predation limitation of fruit set in winter 1996/1997 and winter 1999. Whether the high abundance of this moth was caused by the hurricanes cannot be ascertained because hurricanes occurred in both years, and no pre-hurricane information exists. Possibly, hurricanes reduced its predators, although insectivorous birds were not reduced after Hurricane Lili (Murphy et al. 1998). Or perhaps this moth responded to the unusually abundant floral resources of $B$. succulenta. Larvae, however, were common in buds, flowers, and fruit on three of the four shrubs seen flowering in June 1999 when flowering was extremely sparse; only four shrubs had some flowers in a general survey of hundreds of shrubs on the island. Therefore, the high predation may not be unusual and may be unrelated to the hurricanes. In any event, the moth predator was not saturated by the unusually abundant flowering in winter 1996/1997, and the high predation, coupled with pollination limitation, caused extremely low fruit set in $B$. succulenta. In contrast, Pascarella (1998b) found that high levels 
of flowering satiated a moth predator and predation levels were low the year immediately following a hurricane.

Whether resource limitation would have reduced fruit set from a maximum as was seen for another species, $P$. bahamensis, at this site is not known (Rathcke 2000a); however, flowers given unlimited cross-pollen had high fruit set $(77 \%)$ and may not have been resource-limited as has been found in other species (Ackerman \& Montalvo 1990, Bronstein \& Hossert-McKey 1995). Also, the unusually prolific flowering of $B$. succulenta suggests that resources were more available after the hurricane or that this species had a positive reproductive response to leaf stripping and disturbance. With Hurricane Lili, the tops of taller trees were broken and the leaves of most plants were stripped. This may have increased the availability of sunlight and other resources to $B$. succulenta. On the other hand, the leaves of $B$. succulenta were new, indicating that its leaves were also stripped by the hurricane and plants would have had to incur the cost of new leaf production. Bourreria succulenta was the only shrub species at the site exhibiting unusually high flower production after the hurricane. Other species that had their leaves stripped by Hurricane Lili showed normal flower production (e.g., P. bahamensis, Rathcke 2000a) or reduced flower production (e.g., C. haematomma) (Rathcke, pers. obs.).

The low fruit set of $B$. succulenta appears to be unusual for this species, although quantitative data are unavailable to test this. Fruits are commonly collected and eaten by local people (Kass, pers. comm.), suggesting that fruit set can be substantial at times. Examination of past photographs show that single cymes, which typically have 10-20 flowers, had 10-20 fruit, indicating that most of the flowers set fruit. There were no hurricanes on San Salvador between 1981 and 1994 (Shaklee 1996) when these photographs were taken. Whether or not the strong pollination and predation limitation of fruit set seen in this study was caused by hurricane effects or was coincidental, the low fruit set after hurricanes could put this species at a disadvantage for recruitment. Hurricanes can promote the recruitment of new plants by opening gaps in the canopy and can be important in maintaining high diversity in plant communities (Connell 1978, Boucher 1990, Vandermeer et al. 1996). Low fruit set after a hurricane could limit the chances of seedling recruitment. Two years after Hurricane Lili, no $B$. succulenta seedlings were observed, although seedlings of some other shrub species were relatively abundant (Rathcke, pers. obs.).

These results emphasize that a consideration of plant-animal interactions, including pollinators and predators and their unique responses, may be necessary for predicting how disturbances, such as hurricanes, will affect plant recruitment and the maintenance of plant diversity in plant communities. Plant species on small islands like San Salvador $\left(150 \mathrm{~m}^{2}\right)$ or in habitat fragments with few species may be especially vulnerable to disturbances that affect their mutualists or antagonists (Rathcke \& Jules 1993).

\section{ACKNOWLEDGMENTS}

I thank the Bahamian Field Station and the staff for all their support and logistical help, and I thank the following people for their contributions to this study. Jim Ackerman provided valuable editorial suggestions; Lee Kass and Bob Hunt provided continued research and personal support; Susan Danforth helped collect data; Nancy Elliott identified insects and provided valuable insect information; Dave Ewert retrieved information on hurricanes from the Bahamas Department of Meteorology; John Franclemont at Cornell University and Don Davis and David Adamski at the Smithsonian Institution helped identify the moth larvae (Gelechiidae); John Pascarella provided valuable pollinator and nomenclature information and editorial comments; Ken Relyea photographed Bahama Woodstars visiting the flowers of $B$. succulenta at the Bahamian Field Station; and Richard Wunderlin provided nomenclature information.

\section{LITERATURE CITED}

Ackerman, J. D., and A. M. Montat.vo. 1990. Short- and long-term limitations to fruit production in a tropical orchid. Ecology 71: 263-272.

And S. Moya. 1996. Hurricane aftermath: resiliency of an orchid-pollinator interaction in Puerto Rico. Caribb. J. Sci. 32: 369-374.

Al-ShehbaZ, I. A. 1991. The genera of Boraginaceae in the southeastern United States. J. Arnold Arb. (suppl. ser.) 1: $1-169$.

Askins, R. A., And D. N. Ewert. 1991. Impact of Hurricane Hugo on bird populations on St. John, U.S. Virgin Islands. Biotropica 23: $481-487$.

Bahamas Department of Meteorology. n.d. Hurricane Lili in the Bahamas, 18-19 October 1996. Bahamas Dept. of Meteorology, Nassau, Bahamas. 
n.d. Hurricane Erin in the Bahamas, 30 July-2 August 1995. Bahamas Dept. of Meteorology, Nassau, Bahamas.

Baker, H. G., R. W. Cruden, and I. Baker. 1971. Minor parasitism in pollination biology and its community function: the case of Ceiba acuminata. BioScience 21: 1127-1129.

Barrert, S. C. H. 1996. The reproductive biology and genetics of island plants. N. Philosophic. Trans. R. Soc. Lond. B 351: 725-733.

Bolten, A. B., P. Feinsinger, H. G. Baker, and I. Baker. 1979. On the calculation of sugar concentration in Hower nectar. Oecologia 41: 301-304.

Boose, E. R., D. R. Foster, anis M. Fluet. 1994. Hurricane impacts to tropical and temperate forest landscapes. Ecol. Monogr. 64: 369-400.

Boucher, D. H. 1990. Growing back after hurricanes. BioScience 40: 163-166.

Bronstein, J. L., And M. HosserT-MCKky. 1995. Hurricane Andrew and a Florida fig pollination mutualism: resilience of an obligate interaction. Biotropica 27: 373-381.

Camprel.., D. G. 1978. The ephemeral islands: a natural history of the Bahamas. Macmillan, London, England.

Carlquist, S. 1974. Island biology. Columbia University Press, New York, New York.

Connel.t, J. H. 1978. Diversity in tropical forests and coral reefs. Science 199: 1302-1310.

Corrfil., D. S., and H. B. Correli. 1982. Flora of the Bahama archipelago. In J. Cramer (Ed.). A. R. Gantner Verlag Kommanditgeselleschaft, Vaduz, Leichtenstein.

Elliott, N. B. 1993. Field guide to the insects of San Salvador island, Bahamas, 2nd edition. Bahamian Field Station, San Salvador, Bahamas.

, D. Riley, and H. K. Clench. 1980. Annotated list of butterflies of San Salvador island, Bahamas. J. Lepid. Soc. 34: 120-126.

Elmqvist, T., P. A. Cox, W. E. Rainey, and E. D. Pierson. 1992. Restricted pollination on oceanic islands: pollination of Ceiba pentandra by flying foxes in Samoa. Biotropica 24: 15-23.

Eshbaugh, W. H., and T. K. WILson. 1996. On the need to conserve Bahamian floral diversity. In N. B. Elliott, D. C. Edwards, and P. J. Godfrey (Eds.). Proceedings of the Gth symposium on the natural history of the Bahamas, pp. 77-82. Bahamian Field Station, San Salvador, Bahamas.

Feinsinger, P. 1987. Approaches to nectarivore-plant interactions in the New World. Rev. Chilena Hist. Nat. 60: 285-319.

- L. A. Swarm, and J. A. Wolye. 1985. Nectar-feeding birds on Trinidad and Tobago: comparison of diverse and depauperate guilds. Ecol. Monogr. 55: 1-28.

- J. A. WOLFE, AND L. A. SWARM. 1982. Island ecology: reduced hummingbird diversity and the pollination biology of plants, Trinidad and Tobago, West Indies. Ecology 63: 494-506.

Grant, G. S., P. Craic, and P. Trail. 1997. Cyclone-induced shift in foraging behavior of flying foxes in American Samoa. Biotropica 29: 224-228.

Herrera, C. M. 1996. Floral traits and plant adaptation to insect pollinators: a devil's advocate approach. In D. G. Lloyd and S. C. H. Barrett (Eds.). Floral biology: studies in the floral evolution in animal-pollinated plants, pp. 65-87. Chapman and Hall, New York, New York.

INOUE, K. 1993. Evolution of mutualism in plant-pollinator interactions on islands. BioScience 18: 525-536.

Jordan, P. B. 1986. Herbal medicine and home remedies. A potpourri in Bahamian culture. Nassau Guardian Press, Nassau, New Providence, Bahamas. 172 pp.

LoOpe, L. L., AND D. Muell.fr-Dombots. 1989. Characteristics of invaded islands, with special reference to Hawaii. In J. A. Drake, H. A. Mooney, F. di Castri, R. H. Groves, F. J. Kruger, M. Rejmanek, and M. Williamson (Eds.). Biological invasions: a global perspective, pp. 257-280. SCOPE. John Wiley and Sons, New York, New York.

LrNCH, J. F. 1991. Effects of Hurricane Gilbert on birds in a dry tropical forest in the Yucatan peninsula. Biotropica 23: 488-496.

Mili.er, L. D., M. J. Simon, and D. J. Harvey. 1992. The butterflies (Insecta: Lepidoptera) of Crooked, Acklins, and Mayaguana Islands, Bahamas, with a discussion of the biogeographical affinities of the Southern Bahamas and description of a new subspecies by H. K. Clench. Annals of the Carnegie Museum 61: 1-31.

Murphy, M. T., K. L. Cornell, and K. L. Murphy. 1998. Winter bird communities on San Salvador, Bahamas. J. Field Ornithol. 69: 402-414.

OlleRTON, J. 1996. Reconciling ecological processes with phylogenetic patterns: the apparent paradox of plantpollinator systems. J. Ecol. 84: 767-769.

Pascarella, J. B. 1998a. Resiliency and response to hurricane disturbance in a tropical shrub, Ardisia escallonioides (Myrsinaceae), in south Florida. Am. J. Bot. 85: 1207-1215.

$1998 \mathrm{~b}$. Hurricane disturbance, plant-animal interactions, and the reproductive success of a tropical shrub. Biotropica 30: $416-424$.

RATHCKE, B. 1988. Interactions for pollination among coflowering shrubs. Ecology 69: 446-457.

1998. Bird pollination of the endemic Bahama swamp-bush, Pavonia bahamensis Hitchc. (Malvaceae): the risk of specialization. In T. K. Wilson (Ed.). Proceedings of the 7th symposium on the natural history of the Bahamas, pp. 105-110. Bahamian Field Station, San Salvador, Bahamas.

2000a. Hurricane causes resource and pollination limitation of fruit set in a bird-pollinated shrub. Ecology 81: 92-99.

2000b Birds, pollination reliability, and green flowers in an endemic island shrub, Pavonia bahamensis (Malvaceae). Rhodora 102: 392-414. 
AND E. S. Jur.s. 1993. Habitat fragmentation and plant-pollinator interactions. Curr. Sci. 65: $273-277$.

Rathcke, B., L. B. Kass, and R. E. Hunt. 1996. Preliminary observations on plant reproductive biology in mangrove communities on San Salvador island, Bahamas. In N. B. Elliott, D. C. Edwards, and P. J. Godfrey (Eds.). Proceedings of the 6th symposium on the natural history of the Bahamas, pp. 87-96. Bahamian Field Station, San Salvador, Bahamas.

- - AND N. B. El..kotr. 2001. The floral biology and pollination of strongback, Bourreria succulenta (Boraginceae), on San Salvador island, Bahamas. In G. Smith and C. Clark (Eds.). Proceedings of the 8th symposium on the natural history of the Bahamas. Bahamian Field Station, San Salvador, Bahamas. In press.

RfILLY, A. E. 1991. The effects of Hurricane Hugo in three tropical forests in the U.S. Virgin Islands. Biotropica 23: $414-419$.

RLLF, N. D. 1975. A field guide to the butrerflies of the West Indies. William Collins Sons, London, England.

Schemske, D. W. 1983. Limits to specialization and coevolution in plant-animal mutualisms. In M. H. Nitecki (Ed.). Coevolution, pp. 67-110. University of Chicago Press, Chicago, Illinois.

- AND C. C. HoRvrr\% 1984. Variation among floral visitors in pollination ability: a precondition for mutualism specialization. Science 225: 519-521.

Scuriock, J. P. 1987. Native trees and shrubs of the Florida Keys. Laurel Press, Bethel Park, Pennsylvania.

SHAKl.le, R. V. 1996. Weather and climate: San Salvador island, Bahamas. Bahamian Field Station, San Salvador, Bahamas.

SIMBERLOFF, D. 1995. Why do introduced species appear to devastate islands more than mainland areas? Pac. Sci. 49: 87-97.

SMITH, R. R. 1993. Field guide to the vegetation of San Salvador island, The Bahamas, 2nd edition. Bahamian Field Station, San Salvador, Bahamas.

SPEARS, E. E., JR. 1987. Island and mainland pollination ecology of Centrosema Virginianum and Opuntia stricta. J. Ecol. 75: 351-362.

Vandermeer, J., D. Boucher, I. Perfecto, and I. Granzow de la Cerda. 1996. A theory of disturbance and species diversity: evidence from Nicaragua after Hurricane Joan. Biotropica 28: 600-613.

WalDE, R. B, 1991. The effect of Hurricane Hugo on bird populations in the Luquillo Experimental Forest, Puerto Rico. Biotropica 23: 475-480.

Walker, L. R., J. Voltzow, J. D. Ackerman, D. S. Fernandez, and N. Fftcher. 1992. Immediate impact of Hurricane Hugo on a Puerto Rican rain forest. Ecology 73: 691-694.

Wauer, R. H., and J. M. Wunderle, Jr. 1992. The effect of Hurricane Hugo on bird populations on St. Croix, U.S. Virgin Islands. Wilson Bull. 104: 656-669.

White, V. 1985. The outermost island: an oral history of San Salvador, The Bahamas. CCFL Bahamian Field Station, San Salvador, Bahamas.

$\mathrm{W}_{\text {ILL, }}$ T. 1991. Birds of a severely hurricane-damaged Atlantic coastal rain forest in Nicaragua. Biotropica 23: 313 316.

WoOdfll, S. R. J. 1979. The role of unspecialized pollinators in the reproductive success of Aldabran plants. Philosophic Trans. R. Soc. Lond. B. 286: 99-108.

Wundert.., J. M. Jr. 1995. Responses of bird populations in a Puerto Rican forest to Hurricane Hugo: the first 18 months. Condor 97: 879-896.

, D. J. Lodge, AND R. B. WAide. 1992. Short-term effects of Hurricane Gilbert on terrestrial bird populations on Jamaica. Auk 109: 148-166.

Wunderlin, R. D. 1998. Guide to the vascular plants of Florida. University Press of Florida, Gainesville, Florida.

Zimmerman, J. K., E. M. Everham III, R. B. Waide, D. J. Lodge, C. M. Taylor, and N. V. L. Brokaw. 1994. Responses of tree species to hurricane winds in subtropical wet forest in Puerto Rico: implications for tropical tree life histories. J. Ecol. 82: 911-922. 